\title{
Holy Folly: Explorations of Humility in the Kievan Caves Monastery
}

\author{
David K. Prestel \\ Michigan State University, East Lansing, Michigan \\ Prestel@msu.edu
}

\begin{abstract}
Although he does not in important respects fit the traditional paradigm of a Byzantine salos or later Russian iurodiryi, certain aspects of holy foolishness, or perhaps better holy folly, provide insight, in both their presence or absence, for interpreting the tale of the Kievan Caves Monastery monk, Prince Sviatoslav Davidovich (Sviatosha) of Chernigov. The tale is part of a collection of stories about early Caves monks, purported to be a correspondence between its author, Bishop Simon of Suzdal, and the monk Polikarp, which form the core of what later came to be called the Kievan Caves Patericon. Sviatosha's commitment to self-abasement, simplicity, poverty, and denial of high worldly status, takes place within the context of the strictest obedience to the superior, the Caves brethren, and the Studite Rule. The high degree of Christocentricity, self-denial and submission evident in the monastic practice of Sviatosha, as well as that of Feodosii, stands out in two respects. First, though traditionally the sources of Kievan spirituality and monastic practice have been sought in Constantinople or Mount Athos, it is becoming clear, especially when considering Sviatosha and Feodosii, that the spirituality of the Caves Monastery owes much to both Byzantium and contemporary Western monastic practice, such as that of the Cistercians. Secondly, the extraordinary account of the prince-monk, Sviatosha, and the obedience and humility he demonstrates stands out among the Rurikids in a manner that resonates even to the reign of Ivan IV in the sixteenth century.
\end{abstract}

\section{Keywords}

Prince Sviatosha of Chernigov - Feodosii of Kiev - Kievan Caves Monastery - holy folly/foolishness - the Studite Rule - St. Bernard of Clairvaux - Varangian 
When holy foolishness is mentioned in connection with the Kievan Caves Monastery, one immediately thinks of Isaakii Pecherskii, whose tale appears both in the Povest'vremennykh let under 1074 and later in some of the redactions of the Kievan Caves Patericon. ${ }^{1}$ Although he sequestered himself in a cave upon entering the monastery and began living an austere life, Isaakii had neither the experience nor the spiritual discipline to fend off the inevitable demonic attacks. ${ }^{2}$ Therefore, when demons took on the appearance of angels and their elder appeared as an angel of light, whom they honored as the Christ, Isaakii bowed down to him and forthwith came under demonic power. The demons abused him throughout the night and left him for dead in the morning. He remained in a coma for two years, during which time he was treated first rather briefly by Antonii and then Feodosii. ${ }^{3}$ Isaakii finally regained consciousness under Feodosii's care and returned to a life of strict asceticism. He did not withdraw into a cave, however, for we are told that at this stage of his life Isaakii began to play the fool (nacha urodstvo tvoriti). He wore a hair shirt, stood

1 Polnoe sobranie russkikh letopisei, 1, Lavrent'evskaia letopis', $2^{\text {nd }}$ edition (Moscow: Iazyki slavianskoi kul'tury, 2001), cols. 191-198; PSRL, 2, Ipat'evskaia letopis', $2^{\text {nd }}$ edition (Moscow: Iazyki slavianskoi kul'tury, 2001) cols. 182-189. For the text as it appears in the the Kievan Caves Patericon in the Kassian 1462 version, see Dmitrij Tschižewskij, ed., Das Paterikon des Kiever Höhlenklosters, after the edition of D. Abramovich (Munich: Eidos Verlag, 1964), 185-189.

2 See Natalie Challis and Horace W. Dewey, "Divine Folly in Old Kievan Literature: The Tale of Isaac the Cave Dweller," Slavic and East European Journal, vol. 2-3 (Fall 1978), 259-262. Challis and Dewey identify Isaakii's sin as "prelest," defined as "a psychic state akin to fantasy or unhealthy self-delusion" (26o). Prelest' is perhaps best understood in contrast to its opposite, "smirenie" or "true humility," (260). The concept of "smirenie" is well represented in monastic tradition. Douglas Burton-Christie quotes Amma Theodora as saying: "Neither asceticism, nor vigils, nor any kind of suffering are able to save, only genuine humility can do that," The Word in the Desert: Scripture and the Quest for Holiness in Early Christian Monasticism (Oxford: Oxford University Press, 1993), 237. As Burton-Christie states, one naturally relies on the self and trusts in personal achievement for salvation. Asceticism and seclusion are not by themselves the remedy for this self-reliance, only humility as it is manifested in obedience can protect the monk from this type of pride. Amma Syncletica said: 'Obedience is preferable to asceticism. The one teaches pride, the other humility', (Burton-Christie, 237). For a discussion of the role of asceticism in the story see Ludolf Müller, "Die Isakij- Erzählung der 'Nestor-Chronik," Orbis Scriptus Dmitrij Tschižewskij zum 7o. Geburtstag (Munich: Fink Verlag, 1966), 560-71.

3 Prince Iziaslav Iaroslavich, who had fled to the Poles as a result of an uprising against him in Kiev, was angry with Antonii because the latter had condemned him for breaking his oath sworn on the cross to Vseslav Briacheslavich. When Iziaslav returned from Poland, Antonii was compelled to escape to Chernigov and Feodosii took over the care of Isaakii, $P S R L, 1$, cols. 193-194; 2, col.185. 
motionless for long periods of time in church, and in winter his feet would often freeze to the stone. He also served in the kitchen, one of the lowliest jobs in the monastery. While being taunted by a cook, who ordered him to catch a crow, Isaakii actually caught it - an act which likely signifies an extreme form of obedience and led some brethren to honor him. ${ }^{4}$ Isaakii, however, wanted none of that and began to practice foolishness more aggressively, often playing tricks on his superior as well as other monks and laymen. He was frequently beaten for his behavior, but remained humble, patiently enduring all his sufferings. Despite frequently being recognized as one of the earliest examples of Rusian/Russian iurodstvo, however, as well as the fact that Isaakii displays the standard behaviors of the type, some scholars question whether Isaakii should really be considered a "classic" iurodivyi at all. He only adopts these behaviors for a time and his iurodtsvo does not seem to be central to his identity, as is the case with the iurodivye of the fourteenth, fifteenth and sixteenth centuries and earlier Byzantine models, but is subordinate to his stronger identity as an ascetic within a monastery. ${ }^{5}$

4 See Sergey A. Ivanov, Holy Fools in Byzantium and Beyond, Simon Franklin, trans. (Oxford: Oxford University Press, 2006), 253-254. Ivanov suggests that the brethren told Isaakii as a joke to go and catch a crow. Isaakii, however, was unaware of their teasing and caught the bird, an act which Ivanov calls an echo of the "holy simplicity motif."

5 Challis and Dewey maintain that in contrast to Isaakii's use of divine folly as an antidote for prelest': "Divine folly, with its Pauline message directed at targets in the outside world, is more than a phase in the hero's life; it dominates the entire work. Once embarked on jurodstvo, the "foolish" hero remains true to it until death, as though to abandon his strange calling would be to lay down his arms in the never-ending struggle against sophistry and corruption" $(259-262)$. This is an accurate description of classic iurodstvo, but I would note that the Pauline message is not always solely directed at targets in the outside world. His message is often a spiritual charge to believers, which Ivanov seems to recognize. For a brief but succinct and accurate analysis of Isaakii's behavior in the context of Byzantine iurodstvo, see also Muriel Heppell, trans. The Paterik of the Kievan Caves Monastery (Cambridge, MA; Harvard Ukrainian Research Institute, 1989): 228-230. Ivanov notes that on the two occasions that Isaakii "plays the fool," in the first, his holy foolishness is peaceable, but in the second, it is aggressive. It is the latter trait, as we shall see, that is the hallmark of iurodstvo for Ivanov and others. Noting the somewhat abrupt, disconnected quality of the tale, Ivanov makes the perceptive observation that it allows us to see what Byzantine iurodstvo looked like to outsiders (Holy Fools, 254). Svitlana Kobets writes, correctly I think, that the devotional, ascetic, and social goals that the saint pursues have a number of connotations that are in line with paradigmatic Byzantine holy foolishness, yet overall his iurodstvo does not conform to the canonical (Byzantine) models, Priscilla Hunt and Svitlana Kobets, eds., "Isaakii of the Kiev Caves Monastery: An Ascetic Feigning Madness or a Madman-Turned-Saint," Holy Foolishness in Russia: New Perspectives, (Bloomington, IN: Slavica, 2011): 247. 
In the present study, however, I would like to go even further afield and use only certain aspects of iurodstvo to explore how, what we might in this context better call holy folly, can provide some insight into interpreting parts of the tale of another Caves ascetic, Prince Sviatosha of Chernigov, who, I will readily admit, is rarely, if at all, mentioned in relation to iurodstvo. ${ }^{6}$

Before turning to Sviatosha as he is depicted by Bishop Simon in the Kievan Caves Patericon, we should first attempt to obtain some further sense of what is meant by investigators who invoke the notion of paradigmatic Byzantine holy foolishness. ${ }^{7}$ Almost all scholars examining the phenomenon, although recognizing affinities with Old Testament prophets such as Isaiah, Jeremiah, and Ezekiel, cite the Apostle Paul as, at the very least, a significant source for its Christian manifestation. ${ }^{8}$ In 1 Corinthians 4: 10 he writes: "We are fools for

6 Tschižewskij, ed., Das Paterikon, 113-119. Richard Pope points out that the Kievan roots of divine folly are not limited to Isaakii. Following Fedotov he cites Feodosii's youthful posing as a simpleton and notes that the Kievan Caves Patericon has "many hints of nascent divine folly, especially in the case of Gregory the Wonderworker", "Fools and Folly in Old Russia," Slavic Review, 39 (1980): 480-481. Ivanov notes that in the Patericon the verb urod'stvovati is used in a rather unexpected manner. The monk Fedor gained power over demons and forced them to perform heavy labor. They had to obey, but decided to exact revenge. One of them took the form of Fedor's friend Vasilii and told one of the prince's counselors that Fedor was "raving," which Ivanov believes means "to behave in a non-standard way" in this context, Holy Fools, 254-255; Das Paterikon,168). I agree with Muriel Heppell, however, who states that it retains the standard meaning here of "behaving in a mischievous manner that invites taunts and insults," The Paterik, 188, f.n. 591.

7 For a useful and comprehensive overview of iurodstvo in the East and West, see Svitlana Kobets, "Foolishness in Christ: East vs. West," Canadian American Slavic Studies, 34, 3, (2000): 337-363 and the same author's "Lice in the Iron Cap: Holy Foolishness in Perspective," in Holy Foolishness in Russia, 15-40.

8 Examples in the Old Testament are numerous and certainly go beyond these three, who as major prophets are simply among the most prominent. Isaiah 20 describes how Isaiah, after the Assyrians had captured Ashdod, was ordered by the Lord to take off his sackcloth and sandals and walk naked and barefoot for three years as a sign against Egypt and Ethiopia. Jeremiah, because of his denunciation of the sins of Israel and his identification of Nebuchadnezzar as a means of God's justice, was beaten and placed in stocks (Jeremiah 20). In Jeremiah 20: 7 he says: "I have become a laughingstock all day long: everyone mocks me." Ezekiel was called upon to symbolize the forthcoming sufferings of Israel by lying on his side for 390 days and eating only bread and water (Ezekiel 4). Hosea could also be numbered among them: "And the Lord said to Hosea, Go, take unto thee a wife of whoredoms and children of whoredoms: for the land hath committed great whoredom, departing from the Lord. So he went and took Gomer the daughter of Diblaim," Hosea 1: 2-3. The Septuagint has gunaika porneias - wife of fornication for "wife of whoredom," Alfred Rahlfs, ed. (Stuttgart: Deutsche Bibelgesellschaft, 2006). 
Christ's sake, but ye are wise in Christ! We are weak, but ye are strong..." ${ }^{9}$ As Ivanov points out, this particular reference is charged with irony, because Paul, given the numerous shortcomings of the Corinthians, is clearly speaking here with tongue in cheek. ${ }^{10}$ Nonetheless, in relation to the world, not to other Christians like the Corinthians, the Christian message is foolishness." For example, we can cite 1 Corinthians 1: 20-23: "Hath not God made foolish the wisdom of this world? For after that in the wisdom of God, the world through wisdom did not know God, it pleased God through the foolishness of preaching to save them that believe. For Jews require a sign, and the Greeks seek after wisdom; but we preach Christ crucified, unto the Jews a stumbling block and unto the Greeks foolishness." For Paul, in these passages, holy foolishness is centered on the message of the cross, which he elucidates in Philippians 2: 5-9: "Let this mind be in you which was also in Christ Jesus: Who, being in the form of God, thought it not robbery to be equal with God:..... and being found in fashion as a man, he humbled himself and became obedient unto death, even the death of the cross. Wherefore God also hath highly exalted him, and given him a name which is above every name..."

Ivanov is correct, of course, in pointing out the truly significant differences between the Pauline conception of holy foolishness and that of the Byzantine iurodirye such as Andrew Salos and Symeon of Emyssa, who display what he and others say is the sine qua non of iurodivye, namely aggression, "which was

9 All biblical references in English are from the Authorized King James Version unless otherwise noted.

10 Ivanov, Holy Fools, 19. Ivanov writes that Paul knew nothing of what holy foolery was to become, despite the fact that his words have for centuries been cited as the foundation for holy foolishness. Though this is a valid point, we also need to keep the focus on imitatio Christi, which is the basis of holy folly. See 1 Corinthians 3: 18, "If any man among you seemeth to be wise in this world, let him become a fool, that he may be wise." As Jostein Bortnes maintains, "holy foolishness is based on an inverted symbolism, where life on earth in its most humble and despised forms serves as the visible analogue of an invisible glory transcending the world of the senses," Visions of Glory: Studies in Early Russian Hagiography (Oslo, Solum Forlag, 1988), 31. Bortnes maintains that "in accordance with the Pauline 'folly of what we preach,' the humility of the signans is seen as an antithesis to the sublime signatum of the message, the divine Truth, which becomes manifest in the foolish figure of the jurodivye" (Visions, 275).

11 In Kirill of Turov's The Tale of a Layman, the abject poverty of the monk signifies the rejection of the layman, who finds the monastic life foolish, in a way similar to that of the Corinthians, who, though Christians, find Paul's renunciation of the world foolish. See David Prestel, "Ascent to the Cave: Kirill of Turov and Kievan Monasticism," in Kirill of Turov: Bishop, Preacher, Hymnographer, edited by Ingunn Lunde, Slavica Bergensia 2 (Bergen, University of Bergen, 200o), 16. 
to take holy foolery beyond the limits of apostolic foolishness (moria) and into a different sphere for which another term was required... the term was salos."12 Certainly in the practice of Egyptian monks there were already hints of the sort of self-abasement that would become fully developed in the later practice of holy foolishness, and this also implies some degree of simulation. ${ }^{13}$ The key in these instances, is that the holy man or woman, on some occasions, achieved a degree of apatheia or inner passionlessness that enabled her/him to avoid and actually be free of the vices they appeared to display.

Nonetheless, despite the absence of aggression, many of the features that John Saward in his book, Perfect Fools, identifies as key elements of holy folly can be subsumed under the notion of "apostolic folly" (moria), which is the focus of my study. ${ }^{14}$ Saward identifies nine elements: (1) Christocentricity, i.e., Christ crucified, his suffering and humiliation is at the center of the monks' actions (imitatio Christi); (2) folly as charism, a free gift of God; (3) folly as simulated action; (4) folly as eschatological in orientation; (5) folly as a quest; (6) folly as instability — an element of strangeness that clashes with an otherwise closely-knit society; (7) folly as discernment of spirits; (8) and folly as extreme asceticism - reaching apatheia. ${ }^{15}$ In the remainder of this study I will examine the story of Sviatosha within this context, not at all to suggest that he is a salos, which he is not, but to discover how "apostolic folly" as elucidated first by Paul might help us better understand the "Tale of Sviatosha."

For Paul, moria is defined in terms of the wisdom of the world, and specifically Greek thought, which considered any talk of a crucified slave, to be a violation of etiquette. ${ }^{16}$ Anyone who does this is "moros." For the Roman

\footnotetext{
12 Ivanov, Holy Fools, 31.

13 Ibid., 30.

14 John Saward, Perfect Fools: Folly for Christ's Sake in Catholic and Orthodox Theology (Oxford: Oxford University Press, 1980). It should be noted that Kobets from her perspective points out Saward's apologetic tendencies and minimal discussion of the Eastern Orthodox tradition of holy foolishness, "Lice in the Iron Cap," 29. In the present study, however, in which the focus is on monastic spirituality as practiced in the Caves Monastery, these "apologetic tendencies" as Kobets calls them are actually quite helpful. I also consider the tendency to focus exclusively on the Eastern tradition, particularly when treating texts from twelfth-century Rus', to be somewhat limiting and will address this point in greater detail later in my paper.

15 Although aggression itself is not mentioned by Saward, it is apatheia that leads to it. This is precisely what is meant by saying [he/she] "displays vices he lacks" (Ivanov, Holy Fools in Byzantium, 30).

16 G. Bertram, "Moros," in Theological Dictionary of the New Testament, vol. IV, G. Kittel, ed., Geoffrey Bromiley, trans. (Grand Rapids: MI: Eerdmans, 1978), 845-847.
} 
governor, Festus, in Acts 26: 24, Paul's message "that Christ should suffer, and that he should be the first to rise from the dead, and should shew light unto the people and to the Gentiles," was so absurd that he said to him "Paul, thou art beside thyself; Much learning doth make you mad (maniia)." In the New Testament figures such as Festus and Agrippa serve as foils for Paul, representing the world as opposed to the spiritual values of the apostle. Turning to Sviatosha and the story about him in the Kievan Caves Patericon, we see a similar pattern. In this case the foil is Sviatosha's former physician, a Syrian named Peter who ultimately becomes a monk in the monastery and interacts throughout much of the story with the prince.

Sviatoslav Davidovich (Sviatosha/Nikolai) was the son of David Sviatoslavich, prince of Chernigov, and the grandson of Sviatoslav Iaroslavich of Kiev. Chronicle references to Sviatoslav Davidovich are scant. ${ }^{17}$ The Lavrent'evskaia letopis' mentions him twice in conjunction with the conflicts that broke out among the princes after the blinding of Vasil'ko Rostislavich in 1097. When Sviatopolk Iziaslavich of Kiev was defeated by Vasil'ko and his brother Volodar' he retreated to Vladimir-Volynsk accompanied by his two sons, as well as the sons of Iaropolk Iziaslavich (his nephews), and Sviatosha. ${ }^{18}$ Later under the same year, Sviatopolk, who had promised the other princes to move against David Igorevich of Vladimir-Volynsk, sent Putiata, his commander, to meet Sviatosha, who had some retainers of David with him. ${ }^{19}$ Although Sviatosha had promised David to inform him if Sviatopolk were planning to attack him, Sviatosha broke his vow and seized David's men and moved with Putiata against David. ${ }^{20}$

Some context is useful to flesh out Sviatosha's role in this rather dark episode, which followed very soon after the princes had sworn their loyalty on

17 For a good summary of the life of Sviatosha, see Martin Dimnik, "Sviatosha-the First Prince-Monk of Kievan Rus'," in Love of Learning and Devotion to God in Orthodox Monasteries, vol. 1, ed. Miroliub Jokovic, Daniel Collins, M.A. Johnson, Predrag Matejic, [Selected Proceedings of the $5^{\text {th }}$ International Hilandar Conference], (Belgrade/Columbus: ОH: Resource Center for Medieval Slavic Studies, 2006), 258-265. Sviatosha is called Nikolai at the beginning of the story about him in the Kievan Caves Patericon. Dimnik writes that he was given the name Nicholas or Pankratii in baptism, "Sviatosha," (258). Later in that article he maintains that Sviatosha adopted the religious name Nikola (260). Heppell states that Nikola was either his baptismal or monastic name, Paterik, 131, fn. 408.

18 PSRL, 1, col. 270; 2, col. 245.

$19 P S R L, 1$, col. 272; 2, 247. David Igorevich incited Sviatopolk against Vasil'ko and masterminded his capture and blinding, $P S R L, 1$, cols. 257-262; 2, 231-237.

20 Martin Dimnik suggests that Sviatosha may have been forced to imprison David's men by Putiata, The Dynasty of Chernigov 1054-1146, (Toronto: Pontifical Institute of Mediaeval Studies, 1994), 232. 
the cross to each other as part of the Liubech agreement in $1097 .^{21}$ Sviatoslav Iziaslavich was complicit with David Igorevich in the blinding of Vasil'ko, but justified his actions by claiming to have been deceived by David into believing that Vasil'ko had killed his brother Iaropolk Iziaslavich and along with Vladimir Monomakh plotted to kill Sviatopolk and take his lands. Vladimir Monomakh and the Sviaotoslavichi, David and Oleg, although they planned at first to move against Sviatopolk because of his complicity in the crime, were persuaded not to attack Kiev by the populace and metropolitan. Instead, they told Sviatopolk to move against David Igorevich in retribution for his criminal actions. Sviatopolk set out against David with his sons, took Vladimir from David, who fled to the Poles. Sviatopolk then moved against Vasil'ko Rostislavich and his brother Volodar, who defeated him. What is important for us to emphasize here is that the one Sviatoslavich who accompanied Sviatopok Iziaslavich on this campaign was Sviatosha, son of David Sviatoslavich. Martin Dimnik attributes this to the probability that Sviatosha was Sviatopolk's son-in-law, although this is disputed by A.V. Nazarenko, who states that there is no evidence for this marriage beyond Baumgarten, and that Sviatosha's presence on Sviatopolk's campaign against David was likely due to an agreement between Sviatosha's father, David Sviatoslavich and Sviatopolk. ${ }^{22}$ Their subsequent joint actions in 1100/1101 is cited by Nazarenko as evidence of this agreement. At this point there does not seem to be anything untoward about Sviatosha's actions. He appears to be the dutiful son of an honorable father, whose virtues are extolled at length in the Slovo o kniaziakh. ${ }^{23}$

21 See Dimnik, The Dynasty of Chernigov, for a useful treatment of the Liubech agreement and the entire Vasil'ko episode. The events summarized on this page are recorded in the Lavrent'ievskaia letopis' under the year 1097 (6605), cols. 256-273. We should note that just after the beginning of the account, which describes the cross kissing at Liubech, the chronicler writes that "tokmo diavol' pechalen' biashe o liubvi sei," (only the devil was aggrieved at this love), which, it is suggested, was the cause of the grievous events that followed; (col. 257) as the devil incited David Igorevich's men to report to him that Vasil'ko was conspiring with Vladimir Monomakh against him and Sviatopolk.

22 Dimnik maintains that Sviatosha likely married Anne (sic), Sviatoslav's daughter, The Dynasty, 231, fn. 216. He cites as his source N. de Baumgarten, "Généalogies et mariages occidentaux des Rurikides russes du Xe au xıII siècle”, (Orientalia Christiana) vol. ix. No. 35 (Rome, 1927) and Włodzimierz Dworzaczek, Genealogia: Tablice (Warsaw, 1959), which also appears to be based on Baumgarten. Nazarenko is skeptical of this marital connection claiming that Baumgarten gives no sources and it is much more likely that sending Sviatosha with Sviatopolk was intended to strengthen his father's alliances, Drevniaia Rus' i Slaviane (Moscow: Universitet Dmitriia Pozharskogo, 2009), 151-152.

23 Slovo o kniaz'iakh in D.S. Likhachev, L.A. Dmitriev, A.A. Alekseev, N.V. Ponyrko, eds., Biblioteka literatury drevnei Rusi, tom 4, XII vek, (Saint Petersburg: Nauka, 1997), 226-228. 
Further into the story, however, Sviatosha's actions become somewhat more suspect. After David Igorevich defeated the Hungarians with the collaboration of Boniak and the Polovtsy, he moved to retake his patrimony of VladimirVolynsk, which Sviatopolk had given to his son Mstislav. When Mstislav was killed during one of David Igorevich's attacks on the city, Sviatopolk sent his commander Putiata to Lutsk, which Sviatopolk had given to Sviatosha. ${ }^{24}$ Some of David Igorevich's retainers were in Lutsk at that time since Sviatosha had earlier made a pact with David Igorevich to inform him if Sviatopolk were to move against him. ${ }^{25}$ Sviatosha, however, broke his vow, imprisoned David's men, and moved with Putiata against him in Vladimir. The two forces surprised David and after his army was defeated he escaped to the Polovtsy. Sviatosha returned to Lutsk, but David Igorevich, having joined forces with the Polovtsian khan Boniak, attacked Lutsk, and Sviatosha made peace with them while the city was under siege. Then, leaving Lutsk to David Igorevich, he returned to his father, David Sviatoslavich in Chernigov. As Dimnik points out, Sviatosha comported himself well in battle, but he did display a lack of integrity toward David's men, though he may have been compelled to do this by Putiata. ${ }^{26}$ In any case, this is the last we hear of Sviatosha as a prince and the third reference to Sviatosha is entirely different. Under 1106 we are told rather simply that on February 17, Sviatoslav Davidovich "postrizhesia." ${ }^{27}$

We can only guess whether guilt over his betrayal of David's men and the violation of his vow had anything to do with his decision to become a monk nine years later, but there do not seem to be any other plausible explanations. There may be a hint of his motive in the Slovo o kniaziakh, in which his father David Sviatoslavich is praised as having animosity toward no one, and if "anyone raised a campaign against him, he pacified the forces with humility and submission." Further, "if anyone kissed the cross to him, or he himself kissed the cross to someone, he never once in his life transgressed his vow."28

24 This incident is referred to in the Kievan Caves Patericon, but in a very different manner. In the tale about the monks Fedor and Vasilii, Mstislav, in an attempt to find the "Varangian treasure," which was hidden by Fedor, shot Vasilii with an arrow and tortured both monks until they died. This same arrow, according to Polikarp, was the one that killed Mstislav in Vladimir, Das Paterikon, 168-171.

25 The fact that Sviatosha was given Lutsk by Sviatopolk could indicate that he was indeed Sviatopolk's son-in-law, see fn. 23.

26 Dimnik, The Dynasty, 332.

$27 \quad P S R L, \mathrm{I}$, col. 281.

28 Slovo o kniaz'iakh, 226-228. The English translations are taken from The Hagiography of Kievan Rus, translated with an Introduction by Paul Hollingsworth, (Cambridge, MA: Harvard Ukrainian Research Institute, 1992), 225. For the Slovo as a source for 
The Slovo is quite restrained with regard to Sviatosha noting only that "prepodobnyi Nikola Sviatosha ego syn be i ina dva syna," in one redaction and adding a bit more in a different redaction. ${ }^{29}$ Perhaps, we could speculate, that in addition to his earlier transgression, the example of his father worked its way into the prince's conscience. ${ }^{30}$

The main source for Sviatosha's life in the monastery is the tale by Bishop Simon in the Kievan Caves Patericon. There we read that all the monks know about his virtuous life and his obedience. ${ }^{31} \mathrm{He}$ spent three years working in the kitchen and chopped wood to prepare the food, often carrying the firewood on his own shoulders. He served one more year in the kitchen due to his zeal for obedience and then spent another three years at the monastery gate, which he left only to attend church. ${ }^{32}$ Finally, by the will of the superior and the brethren he was permitted to have a cell to himself, which he built, and also planted a garden with his own hands (svoima rukama). It was said that he was never idle and always was engaged in handwork (rukodelie). ${ }^{33}$ Despite the fact that he

contemporary views on "cross kissing," (krestotselovanie) see Yulia Mikhailova and David K. Prestel, "Crosskissing: Keeping One's Word in Twelfth-Century Rus', Slavic Review 70, no. 1 (Spring 2011), 1-22.

"The venerable Nikola Sviatosha was his son and he had two other sons." Slovo 228. The Slovo o Kniaziakh as cited here survives in a fifteenth-century manuscript, which is one of three versions of this sermon. The oldest that survives, in what appears to be a full-length version, Pokhvala i muchenie, sviatykh" muchenik" Borisa i Gleba, dates from the fifteenth century, and a manuscript from the seventeenth century contains the Slovo pokhval'noe na prenesenie sviatykh stratoterpets" Borisa i Gleba. The quotation I have used here is from the Slovo. See The Hagiography of Kievan Rus' 219-228. Hollingsworth uses the Pokhvala i muchenie for his translation, which reads, "Now the venerable Nikolai Sviatosha was his son and [he had] two other sons, and they all pleased God." Hollingsworth notes that only the Encomium (Pokhvala) includes the last clause, $227 \mathrm{fn}$. 195. We should note that David Sviatoslavich actually had five sons and Sviatosha was the eldest, Dimnik, "Sviatosha," 259.

30 Dimnik cites Tsar Boris of Bulgaria and his son Symeon as possible examples for Sviatosha, as well as his father and various relatives who had built churches and monasteries, "Sviatosha," 259.

31 Das Paterikon, 113. Particular attention should be paid to the frequent references to Sviatosha's obedience throughout the tale, especially given his former rank of prince.

Kobets, "Isaakii of the Caves Monastery," 256. Kobets points out that after his experience with demons and his recovery, Isaakii "makes a classical move toward ascetic humility when he finds his place in the kitchen, a typical locale for a holy fool."

33 This is in contrast to Isaakii, who at the beginning of his tale orders others to prepare a goatskin for his hairshirt rather than doing it himself, see Kobets, "Isaakii," 251. This is further proof of Sviatosha's humility. 
had considerable possessions, he gave everything away and even left his wife and children.

As noted earlier, the main part of the tale recounts a series of encounters between Sviatosha and his former physician, named Peter, who was a Syrian. ${ }^{34}$ Peter protested the fasting and privations the prince put himself through and said that his stomach was not used to such food and that his brothers, Iziaslav and Vladimir, had been reproached by others because of the poverty he had assumed. Peter told him: "You have nowhere to recline your head, but you sit in filth, and people think that you have gone out of your mind. What prince has ever done this?"35 Sviatosha's reply included a citation of 2 Corinthians 12: 9 "strength is made perfect in weakness." ${ }^{36} \mathrm{He}$ also states: "I thank the Lord that he has freed me from worldly work and made me a servant to his bondservants, these blessed monks." Sviatosha further tells Peter that to gain eternal life he has made himself destitute for God's sake and to die for Christ would be gain. ${ }^{37}$ As for sitting in filth, Sviatosha states that he reigns with Job, referring to Job 2: 8 "and he sat down among the ashes." ${ }^{38}$ The next stage of the story deals with healing. When Sviatosha falls ill, he recovers before Peter has finished preparing medicines. Once when the physician himself was sick, Sviatosha sent to him and said that if he did not take medicinal herbs he would recover. Peter, however, trusted his own skill rather than the prayers of his former master and took the medicine, which brought him close to death. He recovered only through the prince's intercessory prayers and the next time he fell ill he obeyed Sviatosha's directions and was immediately healed. When the prince announced to him that he would depart this world in three months, Peter launches into a long lament and offers to die for Sviatosha, which in some sense is what then essentially occurs. After his physician's death, Sviatosha lived an additional thirty years, supposedly never leaving the monastery. ${ }^{39}$

\footnotetext{
34 Das Paterikon, 114-117.

35 Ibid., 115. "Ty zhe ne imashi gde glavy pokloniti, na smet'ishche sedia, i mniat' tia iako uzumevshasia." The accusation that he has gone out of his mind, is similar to the Roman governor Festus' charge to Paul, "Much learning doth make you mad" in Acts 26: 24.

36 "v nemoshchi podobno s"vershitisia," Ibid., 115.

37 Ibid., 115 "Mne zhe umreti za Xrista-priobretenie est'." This latter quotation is from Phil.1: 21.

$38 \quad$ Ibid., 115 "a ezhe na smet'ishci sedeti—z Ievom sia tvoru tsarstvuiu."

39 Although according to Simon Sviatosha remained in the monastery after Peter's death and never left until his own death, he did leave once. He was summoned by his cousin Vsevolod Ol'govich of Kiev the year before his death to reconcile the Ol'govichi and Davidovichi to him. In this he was successful, $P S R L, 2$, col. 312. See Dimnik, "Sviatosha," 262. For a full discussion of this episode and its context see his, The Dynasty, $375^{-376}$.
} 
After he died, his brother Iziaslav asked the abbot for some of his possessions, which turned out to have miraculous power.

If we look at Bishop Simon's depiction of Sviatosha in the context of the Apostle Paul's definition of holy folly (moria), we see a number of parallels. Sviatosha humbled himself. He worked at menial jobs in the monastery and lived in a manner that was completely inappropriate for a prince. This becomes very apparent in the protracted exchanges he has with Peter, which appears to be their purpose. ${ }^{40}$ His life in the monastery is characterized by obedience to the brethren, his superior and to God. His brothers, Iziaslav and Vladimir, are reproached because of his actions and his boyars are in despair, due to the loss of their prince. People think that he has gone out of his mind, for he has nowhere to lay his head and sits in filth. In his own explanation of his behavior, Sviatosha states that he decided not to spare his flesh, in order that his body, crushed by labor, might find peace.

Moving a bit beyond Pauline moria, however, I want to return to Saward's key elements of holy folly to see whether we might find parallels there as well. His first element is Christocentricity, which we could describe more purposefully as imitatio Christi. In Philippians 2: $5^{-8}$, cited earlier, Christ, although in the form of God, "humbled himself and became obedient to the point of death, even the death of the cross." At the beginning of Sviatosha's tale, we read that having considered the vanity and fleeting nature of the world, he "left behind his principality, his honor, glory and power, and reckoning them all as nothing, came to the Caves Monastery and became a monk."41 This description already identifies Sviatosha as a rare exception in the world, for Paul, in 1 Corinthians 1: 26 writes: "For ye see your calling, brethren, how that not many wise after the flesh, not many mighty, not many noble, are called." The physician's question to his former master, "What prince ever did this (Kij ubo kniaz' se s'tvori,)" resonates in this context, for the answer is clearly no one. ${ }^{42}$ Furthermore, not only did Sviatosha leave behind his power and wealth, but he became a kitchen worker and doorkeeper in the monastery, two of the most humble occupations for monks. Like Christ, who states in Matthew 8: 20 that "foxes have holes, and

The persons who act as foils, whether Festus in Acts 26, or the Syrian Peter in this story, serve to make more clear the "transvaluation" of values in the New Testament. Bortnes calls this "inverted symbolism," in which "life on earth in its most humble and despised forms serves as the visible analogue of an invisible glory transcending the world...," Bortnes, Visions, 31.

41 Das Paterikon, 113.

42 No one in Rus' that is. Dimnik, however, provides examples from Bulgaria-Tsar Boris (d. 889) and his son Simeon (d. 923), "Sviatosha," 259. There are no references to Boris, to my knowledge, in any of the texts associated with Sviatosha. 
birds of the air have nests, but the Son of Man hath not where to lay his head," Sviatosha, according to Peter has no place of his own. His expected death is also ignominious, for Peter says "when you depart this life you will be clothed in these patched clothes," in contrast to the elaborate burial of a prince. ${ }^{43}$ Related to death also, is the parallel of predicting one's passing. Christ's predictions of his coming death are misunderstood by his disciple, the Apostle Peter in Matthew 16: 21-23, just as Peter the Syrian physician (aptly named) is confused and misunderstands Sviatosha's prediction about his death. It is noteworthy also in terms of imitatio Christi that his cited term of service at his posts in the monastery is three years and his time in the Caves after the death of Peter is thirty years, which was Christ's life span before his three years of ministry. ${ }^{44}$

The second element of holy folly mentioned by Saward is its nature as a gift of God through the Holy Spirit (charisma). Although there seem to be no direct connections here, Sviatosha recognizes that his decision to humble himself and become a servant comes from God. As noted above, at one point he says to Peter, "I thank the Lord that he has freed me from the work of this world and has made me a servant to his bond servants, these blessed monks." 45

Where Sviatosha clearly differs from traditional or "classic" holy fools is in the character of holy foolishness as simulated action, which is Saward's third element. This relates to the prophetic or "aggressive" side of holy foolishness as defined by Ivanov and it clearly differentiates Sviatosha from Andrew Salos and even Isaakii Pecherskii. ${ }^{46}$ Sviatosha became a servant and gave up his rich clothing to sit naked, and in this he is also similar to Christ. In his obedience he does things that in the world's view are unseemly to his station, which is why his brothers are reproached and some say that he has gone out of his mind. ${ }^{47}$ He does this to demonstrate that he trusts God completely for his sustenance and has pledged obedience to the prior and to the Studite Rule. Echoing the

\footnotetext{
43 Ibid., 116.

44 See fn. 36.

45 Das Paterikon, 115. Spiritual discernment can also be considered a charism, of course, but Saward lists it as a separate category and it will be discussed below.

46 Some scholars point to mental illness as the cause of the behavior of Isaakii and other iurodivye. Bortnes, however, maintains, correctly in my view, that "the humility of the signans is seen as an antithesis to the sublime signatum of the message, the divine Truth... This semiotic character distinguishes the holy fool in principle from all forms of 'natural imbecility' and madness," Visions, 275.

47 One is also reminded of the Apostle Paul who, as noted earlier, was told by Festus that he must be mad, in confessing that the Jesus who died on the cross is the Messiah (Acts 26).
} 
Gospel of Matthew, Sviatosha tells Peter that trust should be put in God, not man. ${ }^{48}$

Saward's fourth, fifth and sixth elements, which present holy folly respectively as eschatological in nature, a quest, and a reflection of instability are more helpful in discerning features of apostolic holy folly in Sviatosha's spiritual practice. His decision to abandon the present world is clearly presented in an eschatological context, for Simon writes at the beginning of the tale that "the blessings of the world to come are eternal and will not pass away and the heavenly kingdom, which God has prepared for those who love him is without end."49 Sviatosha himself, quoting from Romans says: "The sufferings of this present time are not to be compared with the future glory that will be revealed in us." ${ }^{50}$ This promise also has echoes of imitatio Christi, for the passage cited earlier in Philippians concludes with the statement that because Christ humbled himself unto death, "God also hath highly exalted Him and given Him a name which is above every name..."

The notion of a quest, which generally involves a sojourn to a foreign land is more difficult to support, but there is a curious mixing of the identities of Sviatosha and Peter in the story, and Peter laments what he believes is the imminent death of the prince by asking who will look after him (Peter) as a foreigner, but it is Peter, of course, who dies. ${ }^{52}$ In addition, many of the references to Sviatosha in the tale, refer to him as absent and although he is in the monastery in Kiev, he may as well be in a distant land in comparison to his involvement with his former life and station. ${ }^{53}$ This also ties into the idea of instability. The former, stable world of Chernigov, in which Sviatosha's brothers looked up to him, the boyars depended on him, and the physician counted heavily on his favor, is now turned upside down and his brothers suffer insults, the boyars are despondent and the physician is left without a benefactor. Only Sviatosha is at peace sitting in filth.

Finally, folly as spiritual discernment and extreme asceticism are, as we have seen, readily apparent in the tale of Sviatosha. The prince knows that the physician will regain his health if he does not take medicines and then predicts his death, first three months beforehand and then three days. Sviatosha's

\footnotetext{
48 Matthew 6: 25-31.

49 Das Paterikon, 113.

50 Das Paterikon, 115 . See Romans 8: 18 .

51 Philippians 2: 9.

52 Peter mistakenly believes that Sviatosha is referring to his own death, not Peter's.

53 This sense of distance is also emphasized by the claim that Sviatosha remained in the monastery thirty years without leaving.
} 
asceticism is undisputed. He gave everything away, worked at humble positions in the kitchen and at the gate, and built his cell with his own hands. As noted above, we are told that after the death of the physician, Sviatosha remained in the monastery for thirty years, not leaving until his death, which though not true according to other sources, is a common topos for extreme asceticism. ${ }^{54}$

Although St. Feodosii of the Caves is not generally regarded as a holy fool, as his "nocturnal penance" suggests, he practiced an extreme form of asceticism as well. In addition, Richard Pope points out that Feodosii's youthful posing as a simpleton could be viewed as iurodstvo. ${ }^{55}$ Given their similarities, it is not surprising that Feodosii and Sviatosha are linked, particularly in accounts of miracles. At the end of his tale, Simon recounts an incident that occurred after the prince's death. When Sviatosha's brother Iziaslav Davidovich fell ill, he raised himself in his bed and asked for water from the well of the Caves Monastery. They sent for water from the well, with which the tomb of Feodosii had been wiped. In addition, the superior gave the messenger Sviatosha's hairshirt. Before the man came into Iziaslav's room, the prince raised himself in his bed and said: "Go quickly before the town to meet the venerable Feodosii and Nikola!" ${ }^{6} \mathrm{He}$ was immediately healed when he was given the water and dressed in Sviatosha's hairshirt. ${ }^{57}$

In addition to this reference to Feodosii, Dimnik and Heppell have pointed out a second posthumous reference that links the two. ${ }^{58}$ Bishop Nifont of Novgorod travelled to Kiev, fell ill and died. Three days before his illness he dreamed that he was in Sviatosha's place in the Church of the Assumption in the Caves Monastery praying that he might see Feodosii. In answer to his prayers, a monk led him to the altar and showed him the saint's body. Feodosii

54 See fn. 33. Similarly, according to the Povest'vremennykh let, Antonii remained in his cave for forty years without leaving, but this also is contradicted by the fact that when Prince Iziaslav returned from Poland, we are told that Antonii fled to Chernigov, PSRL, 1, cols. $15^{8}$ and 193-194. The numbers thirty and forty are symbolic of the life of Christ before his ministry, the sojourn of the Israelites in the wilderness, and the number of days Christ was tempted in the wilderness.

His "nocturnal penance" penance refers to Feodosii's practice of spending the night outdoors with his body bared and exposed to mosquitoes and other insects, Bortnes, Visions, 77. For Pope's comments see "Fools and Folly," 480-481.

56 Das Paterikon, 117.

57 Das Paterikon., 118. Iziaslav always wore the hairshirt after this in battle and was not harmed. Once, however, after he had sinned, he did not dare wear it and was killed. For the account of his death in 1162 see $P S R L, 2$, col. 518 . There is no mention of the hairshirt in the chronicle account.

$5^{8}$ Dimnik, "Sviatosha," 263; Heppell, Paterik," 110-112. 
rose up, blessed him and foretold his death. ${ }^{59}$ Dimnik uses both these episodes to suggest that Sviatosha had a spiritual eminence among the faithful comparable to that of Feodosii, ${ }^{60}$ Although this claim may be rather difficult to substantiate fully on the basis of these two episodes, at the very least they do draw attention to the similarities in the spiritual practice of both monks and attest to connections between them that were recognized in the monastery.

Jostein Børtnes has written very persuasively about the Life of Feodosii and its ties to Bernard of Clairvaux and Cistercian monastic ideals. ${ }^{61}$ Key to this again is the concept of imitatio Christi. Bernard maintained that the striving for ascent and glorification had been implanted in man by God. In the natural man, however, this turns into the glorification of the self, which results in pride and arrogance. In contrast, by following the example of Christ and following him through a path of lowliness and abasement, one is able to share in his ascension and glory. ${ }^{2}$ We could argue that even more than Feodosii, who came from a noble family and yet adopted an ascetic life style based on humility and suffering, Sviatosha, the former prince, represents a level of debasement and assumed lowliness seldom encountered in Orthodox monasticism, but one that brings him yet closer to the ideal established by Christ. ${ }^{63}$ Obedience, humility and the hope of glorification are clearly the ascetic ideals that motivate Sviatosha.

These are ideals that also fit well with the connections and similarities between the Caves Monastery, Bernard of Clairvaux, and the early Cistercians identified by Børtnes. As noted above, Børtnes sees Theodosius' imitatio Christi

59 Dimnik "Sviatosha," notes that Nifont died in 1156, indicating that Sviatosha's memory was still alive in the monastery thirteen years after his death, 263 . Also see Heppell, 111-112. The account of Nifont's dream is found in the Kassian edition of the KCP, Das Paterikon, 97-98. For the chronicle account of Nifont's death see $P S R L, 2,483-484$.

6o Dimnik, "Sviatosha," 263. The close connection to Feodosii can also be used to counter arguments that Sviatosha's humility and sincerity are suspect, which will be dealt with in greater length below.

61 Jostein Bortnes, Visions of Glory, 79-81.

62 Ibid., 80.

63 It is worth noting in this respect that in the sixteenth-century Stepennaia kniga Sviatosha is given greater prominence than Feodosii in the sections dealing with the Caves Monastery. Because he was a prince and a member of the Riurikid dynasty, this is not surprising, but it still speaks very positively concerning the status of Sviatosha among the Orthodox faithful, Gail D. Lenkhoff and Nikolai N. Pokrovskii, eds. Stepennaia kniga tsarskogo rodosloviia, vol. 1 (Moscow: Iazyki slavianskikh kul'tur, 2007), 387-401. See also David Prestel, "Creating Redemptive History: The Role of the Kievan Caves Monastery in the Stepennaia kniga," The Book of Royal Degrees and the Genesis of Russian Historical Consciousness, Gail Lenhoff and Ann Kleimola eds. (Bloomington, IN: Slavica, 2011: 97-109. 
as "closely related to the saintly ideal of the late Middle Ages in Western Europe, to both the Franciscan version and the one conveyed in the writings of Bernard of Clairvaux." 64 I believe that it is not at all an exaggeration to say the same of Sviatosha. It is helpful, therefore, when discussing holy folly in the context of the Kievan Caves Monastery to consider Saward's answer to the question of how we are to relate Cistercian "folly" to the classical paradigm of holy foolishness in the Eastern tradition. He notes the expected correspondences of Christocentricity, nonconformity to the world, poverty, and simplicity, but states: "there is this difference: like the desert monks, especially the anchorites, the Cistercians had too vivid a sense of the absolute nature of every monk's vocation to admit the possibility of a more extreme way of life within their own monastic family." ${ }^{55}$ The high degree of Christocentricity, self-denial and obedience evident in the monastic lives of Feodosii and especially of Sviatosha bear strong witness of their place in this coenobitic tradition. Indeed the case could be made that this is a key element in Kievan Caves spirituality and is prominent in the stories of many of the monks depicted in the Kievan Caves Patericon. ${ }^{66}$ With regard to Sviatosha, his commitment to self-abasement, simplicity, poverty, and denial of high worldly status, takes place within the context of the strictest obedience to the superior, brethren, and the Studite Rule. ${ }^{67}$

64 Bortnes, Visions, 79 .

65 Saward, Holy Fools, 78.

66 This is obviously not true of all the monks depicted in the $K C P$, but it seems to me that careful analysis would reveal a larger number than we might have expected, For a traditional view that emphasizes the extreme asceticism of the Caves Monks, see G.P. Fedotov's separation of Caves monastic practice into the respective schools of Anthony and Theodosius, The Russian Religious Mind (New York: Harper and Row, 1946), 142-157.

67 For the Studite Rule and its role in the Kievan Caves Monastery, see A.M. Pentkovskii, Tipikon Patriarkha Aleksiia Studita v Vizantii i na Rusi (Moscow: Izdatel'stvo Moskovskoi Patriarkhii, 2001), which consists of two parts. The first part is a study of the Typikon and its role in Studite monastic traditions in Byzantium and Rus' and the second consists of a complete edition of the Church Slavonic translation of the Greek Typikon that is based on the Moscow Synod manuscript 330/380. Two versions of the introduction of the Studite Rule into the Caves Monastery exist. According to the account in the Zhitie Feodosii, Feodosii sent to the former monk, Efrem in Constantinople to send back the rule, Uspenskii Sbornik XII-XIII vv. ed. S.I. Kotkov, (Moscow: Nauka, 1971), 89. In the PVL under 1051, Efrem is not mentioned and we are told that Feodosii obtained a copy of the rule from a Studite monk named Michael who had come from the Greeks with Metropolitan George to Kiev, $P S R L$, 1: 160 and 2:148. Despite some minor discrepancies, it is possible, as Heppell suggests, that the two sources could be complementary (Paterik: 44, f.n. 152). Pentkovskii maintains that the heading of the ktetorikon section of the Studiisko-Aleksievskii ustav (368) is very similar to the passage in the $P V L$ that describes the monastic practice that 
In Western Europe in the eleventh and twelfth centuries, monastic reform involved a rediscovery of the "desert", a special emphasis on poverty, and a devotion to the Rule of St. Benedict, which resulted in fusion of the eremitic tradition of the East and the coenobitic tradition of the Rule. ${ }^{68}$ The similarities between this and the spiritual life practiced by Feodosii and Sviatosha, with the Studite Rule replacing the Rule of St. Benedict, are readily apparent. ${ }^{69}$

The connection with the spirituality of the Christian West in addition to the undeniable influence of Byzantine Orthodoxy can also be seen in the growing interest among scholars of Rus' to look beyond the traditional focus on Constantinople as the sole source for the spiritual life of the Caves Monastery in its early years. Based on the account of the founding of the Caves Monastery in the $P V L$ under 1051, Fairy von Lilienfeld, in her article "The Spirituality of the Early Caves Monastery," which was published in 1993, refers to the Caves as a monastery "of the desert."70 Turning to the core stories of the Caves Patericon compiled by Bishop Simon and Polikarp, she notes that "a heavy emphasis is placed on the connection of the monastery with Constantinople."71 John Lind,

Feodosii established when he obtained the typikon (PSRL 1: 160 and 2: 148-149). He believes that this indicates that the chronicle reference is to the Studiisko-Aleksievskii ustav itself and not a short version that was translated before the full typikon (157). He goes on to state that the establishment of the monastic and liturgical practice in the Caves would have depended not only on the typikon, but on a range of liturgical works that must have been available at the time of Feodosii (158). Also see Boris A. Uspenskii, "Antonii Pecherskii i nachal'naia istoriia russkogo monashestva (Riasofor v Drevnei Rusi)," Slověne, 2016 No. 1, 83-85. Because the Studite Rule was introduced by Feodosii its introduction had to have been between 1062 and his death in 1074. Uspenskii states that the choice of this particular ustav, was determined by its connections to the Studite tradition of Theodore the Studite, but the rule established by him has not survived, athough the Studiisko-Aleksevskii ustav reflects the original Studite tradition, 83 .

68 Janet Burton and Julie Kerr, The Cistercians in the Middle Ages (Woodbridge, Suffolk: The Boydell Press, 2011), 16-17.

69 Rosemary Morris maintains that though Byzantine monasticism did not possess the "rules" that united the Benedictines and Cistercians in the West, Studite practice became the basis of the typika in many monasteries in Byzantium and as far away as the Caves Monastery in Kiev, Monks and laymen in Byzantium, 843-1118 (Cambridge, Cambridge University Press, 1995), 217-218.

$70 \quad$ Fairy von Lilienfeld, "The Spirituality of the Early Kievan Caves Monastery," in Christianity and the Eastern Slavs, vol. 1 Slavic Cultures in the Middle Ages, Boris Gasparov and Olga Raevsky-Hughes, eds. (Berkeley: University of California Press, 1993), 65.

71 Ibid, 63. According to von Lilienfeld, the account in the $P V L$, particularly in relation to Antonii, "harps upon the fact that the ксм had been founded by the "blessing of the Holy Mount Athos," which Antonii had brought from the prior who tonsured him," 72. In contrast, the core stories of Simon and Polikarp, emphasize "the close connection of 
in a recent article that traces numerous connections to Latin Christianity in the Kievan Caves Patericon, maintains that the stories he cites seem "to disprove Fairy von Lilienfeld's claim that the Paterik shows the Caves Monastery to be 'not only a stronghold of piety, but also of the Constantinople connection,' i.e., of the 'Greek faith,' opposed to the Latin one..."72 In fairness to von Lilienfeld, the footnote from which Lind is quoting seems to be referring to the orientation of the fifteenth-century Russian redactors of the final corpus of the Kievan Caves Patericon, and not that of Simon and Polikarp. ${ }^{73}$ In addition, von Lilienfeld stresses the multinational nature of the monastery and maintains that although in the thirteenth century in eastern Europe "a new exclusiveness, a consciousness of Rus' nationality," arose, one finds nothing of this sort in the ксм in the eleventh and twelfth centuries,- -and not even in the tales of Simon and Polikarp in the thirteenth century. ${ }^{74}$ Just the same, however, Lind's thorough study of the positive attitude toward Varangians in the Kievan Caves Monastery as displayed primarily in Simon's first three tales, but also in other references to Varangians, lead him to question an exclusive focus on Constantinople in the early history of the Kievan Caves Monastery. ${ }^{75}$ Referring to the three tales by Bishop Simon that recount the building of the cathedral of the Dormition of the Theotokos in the Kievan Caves Patericon, Lind traces the role of a Varangian prince, Shimon/Simon, whose visions and subsequent generosity were instrumental in the building of the church. ${ }^{76}$ The second and third tales, in which Shimon/Simon is referred to only as the Varangian, further emphasize the significant role he played in the foundation of the monastery. ${ }^{77}$ Lind cites other passages in the Patericon that reflect positively on Varangians and although, I am not sure that I can agree with his statement that the Varangians were "co-founders of the Christianity that came to be practiced

the monastery with Constantinople," 63 . On the two traditions in the monastery, see also Pentkovskii, 157 .

72 John H. Lind, "Christianity on the move: the role of the Varangians in Rus and Scandinavia," in Byzantium and the Viking World, Fedir Androshchuk, Jonathan Shepard, and Monica White, (Uppsala: Uppsala Universitet, 2016), 424.

73 von Lilienfeld, 73 .

74 von Lilienfeld, 73 .

75 Lind, $421-436$.

76 Ibid., 425. The name change pronounced by Antonii from Shimon to Simon may reflect the Abram/Abraham and Sarai/Sarah changes in Genesis, which came directly from God. The Saul/Paul combination is tempting to cite, but is probably not relevant as Acts 13: 9, which records the first use of the name Paul states: Saul, also called Paul, is not a change in his name, but likely indicates that as a Roman citizen he had a Jewish name Saul as well as a Roman name Paul (Paulus-Latin, Paulos-Greek).

Ibid., 425 . 
there," his thorough investigation of what the designation Varangian Christianity meant and the role it played in Caves spirituality deserves to be taken seriously.

Although clearly beyond the scope of this study, when one considers the similarities between the spiritual practice of Feodosii and Sviatosha as described in the texts associated with the Caves monastery, as well as the similarities that both Saward and Børtnes point out between the stories in the Caves Patericon with the Cistercian movement and Western monasticism of the same period, it becomes apparent that further study of these connections is needed. The interrelationships noted by Lind and even von Lilienthal are also intriguing and although warning signs appear in the form of negative references to "Latinist" practice, some of these may very well be later accretions. ${ }^{78}$ It is rapidly becoming clear that the connections between the monastery and Western Europe are certainly sufficient enough in number to justify more comprehensive analysis in future studies, which one hopes will firmly establish the claim made by Lind that the spiritual life practiced by the monks of the Caves Monastery owes much in one way or another to both Byzantium and the West and that excluding either only leads to a partial or even distorted picture. The thirteenth-century tales related by Simon and Polikarp offer rich material for such investigations and deserve increased scholarly consideration in the future.

Returning to Sviatosha and, at the risk of introducing a sour note in describing his monastic practice before moving to the conclusion of the study, I think it worthwhile to address concerns that F.M. Murianov expressed in an article published in 1968, with regard to Sviatosha's sincerity. Murianov finds it difficult to accept the prince's extreme humility and suggests that the use of the word "sviatosha" in Russian to designate a hypocrite or sanctimonious person, could be traced directly back to Nikola Sviatosha. ${ }^{79}$ After listing a number of the positive traits of Sviatosha, Murianov points out some indications in Simon's tale that the prince's modesty was not altogether sincere. Simon writes that on the day of Sviatosha's death, close to the entire city gathered, which

78 Lind, 428-429. Noting that at the end of the first tale a "kind of epilogue is attached," in which Shimon/Simon is described as having become a "Christian," and "leaving behind Latin Error." Lind views this as reflecting more militant values that began to develop from the mid-twelfth century on (428). Also see Heppell, p. 5, fn. 17.

79 M.F. Mur'ianov, "Sviatosha Nikola," Wiener Slavistisches Jahrbuch 14 (1967-68): 88-93. Vladimir Dal' lists "sviatoi or pravednik" as archaic meanings and "khanzha" sviatets" and pustosviat" as contemporary (1882) meanings of the word, Tolkovyi slovar' velikorusskogo iazyka, tom IV (Moscow, Gosudarstvennoe izdatel'stvo inostrannykh i natsional'nykh slovarei, 1955), 162. 
could suggest according to Murianov, that he did not want to live or die unnoticed. In addition, Sviatosha seems to boast of the fact that he was the only Rus' prince to have become a monk voluntarily and adopted an extreme ascetic life style. Closer reading of the text, however, indicates that Sviatosha is not boasting. He concurs that he is the only Rus' prince to have chosen this life, but he does so in response to the physician Peter's question, "What other Rus' prince has done this?" The reference to the whole town gathering at his death, is very likely a commonplace, appropriate to princes and respected spiritual leaders, and can hardly be attributed to Sviatosha's pride.

Murianov also cites Sviatosha's betrayal of David Igorevich as evidence of his hypocrisy. As has been mentioned, David was largely responsible for the blinding of Vasilko and many of the princes turned against him. More importantly, however, this incident occurred before Sviatosha's entry into the monastery and may have even contributed to his decision to do so. A sinner turning to God in repentance, is not an unusual circumstance in the Christian tradition. One need only cite the Apostle Paul, who persecuted Christians before his conversion.

In addition, Murianov builds a case for Latin leanings on the part of Sviatosha, based on his request for a translation of a letter by Pope Leo I concerning the two natures of Christ. What Murianov is referring to, however, is the Epistle to Flavian, written by Pope Leo I to Bishop Flavian of Constantinople against the Monophysite monk Eutyches, which bears rather scant testimony to "Latin leanings." 80

Murianov suggests that coupled with his betrayal and false modesty, all these actions could have led to Sviatosha's name becoming synonymous with hypocrisy. We must note, however, that there is no evidence of perceived hypocrisy in Sviatosha in the Kievan Caves Patericon or chronicles. Later references, such as those already mentioned in the Stepennaia kniga are also devoid of any such concerns about his sincerity. The connection of the word, "sviatosha" with hypocrisy, seems to have had a rather late origin and the original meaning of a saint or righteous man likely survived at least into the nineteenth century. ${ }^{81}$

I will conclude, more positively, by returning to the concept of holy foolishness with which this study began. Although, as I trust I have made clear, it has

8o Dimnik claims that the translation Sviatosha requests, which was completed after Sviatosha's death, "became an aid to Kievan preachers and polemicists." He cites Klim Smoliatich as one of the first to use it," "Sviatosha," 261. For evidence of this see Simon Franklin, trans., intro., Sermons and Rhetoric of Kievan Rus' (Cambridge, MA: Harvard Ukrainian Research Institute, 1991), lxxi.

81 Murianov, 88. 
not at all been my intention to demonstrate that Sviatosha is a iurodivyi (and, quite frankly, do not find that question to be a particularly relevant one for twelfth-century Rus'), in terms of posterity, and bolstering Sviatosha's reputation after the previous section, it is worthwhile to take a brief look at how he fared after his death. We have already cited a rather positive treatment in one of the three redactions of the Slovo o kniaziakh, and Dimnik mentions a princeling who "thought to imitate the divine Sviatosha" and entered the Monastery of Volokolamsk in the latter half of the fifteenth century, as well as reference to him as a spiritual model in a collection of the Kirillo-Belozerskii Monastery. ${ }^{82}$

Most telling, however is the possible response to an observation and then a question posed by Ivanov, who writes: "Apparently, Ivan the Terrible regarded the status of holy fools as being in some respects equal to the status of tsar. In the Book of Degrees of the Tsars' Genealogy, [Stepennaia kniga] compiled under his patronage, in a eulogy to the descendants of Prince Vladimir we suddenly find the following passage:

Some...were reckoned fools for Christ's sake and deigned to live in the way of poverty and homelessness, and with much arduous wandering, and were saved; theirs are innumerable names of incalculable nobility, which are inscribed in the heavens, and their memory on earth abides with praises forever.

Ivanov then continues with the question: "Which of Vladimir's descendants were considered holy fools in sixteenth-century Moscow we can only guess." 83

Perhaps it is only a guess, but it is noteworthy that Step three of the Stepennaia kniga covers the reign of Vsevolod Iaroslavich and five metropolitans and contains material from the Kievan Caves Patericon. ${ }^{84}$ Although Antonii and Fedosii are mentioned only a very few times in passing, a full third of the text in Step three is devoted to Sviatosha. As I wrote in an earlier article, according that amount of attention to Sviatosha, and in comparison, all but ignoring the contributions and influence of Antonii and Feodosii is very likely an attempt to transfer at least some of the considerable spiritual value of the Caves Monastery to the Rurikid dynasty. ${ }^{85}$ Given the prominent role played by Sviatosha in the Stepennaia kniga, and the extraordinary humility (smirenie), Christocentricity and self-denial ascribed to him by Bishop Simon, it appears likely that the passage quoted by Ivanov above, refers, at least in part, to him.

\footnotetext{
82 Dimnik, Sviatosha, $263-264$.

83 Ivanov, 291.

84 Lenhoff and Pokrovskii, $386-401$.

85 David Prestel, “Creating Redemptive History," 109.
} 